\title{
Water environment pollution with its impact on human diseases in India
}

\begin{abstract}
The problem of water pollution in India is not a new one. It has been an age- old practice that people dispose of their waste into rivers and other water bodies. The consumption of polluted water is intimately connected with the occurrence of many deadly diseases. Rapid and unplanned population growth in India is a key factor to the whole equation of water pollution. This paper provides an overview of population growth, the mechanism of water pollutant load, causes of water pollution in India as well as the diseases resulting from the use of polluted water.
\end{abstract}

Keywords: water pollution, micro organism, sewage, diseases, cholera
Volume 4 Issue 4 - 2020

\section{Rakhecha PR}

Independent researcher: D-82, Shastri Nagar, Jodhpur- 342003, Formerly at: Indian Institute of Tropical Meteorology, Pune, India

Correspondence: Rakhecha PR, Independent researcher: D-82, Shastri Nagar, Jodhpur- 342003, Formerly at: Indian Institute of Tropical Meteorology, Pune, India,

Tel + 91 29l 2639449, Email rakhechaukhraj@gmail.com

Received: June 16, 2020 | Published: August 04, 2020

\section{Introduction}

Water is a vital natural resource which is considered absolutely essential for sustaining all forms of life in the biosphere. As such the water security has played a significant role in controlling the distribution of human settlements over the surface of the earth. Rivers are the greatest source of fresh water; as a result most of the people settled on river banks. Going back in history before industrial revolution, it was possible to withdraw and consume water from the water bodies to everyone's satisfaction. However, times have changed and over the past few decades most of the countries of the world are facing the tremendous increase in the human population, increasing urbanization and endless industrialization. All of these cause an alarming flow of municipal sewage and industrial waste into rivers, lakes and aquifers and greatly pollute our water bodies.

According to $\mathrm{UNESCO}^{1}$ usage water pollution is defined as the introduction into water of any substance in undesirable concentration not normally present in water, for example, microorganisms, chemicals, waste or sewage, which renders the water unfit for its intended use. In other words water pollution is defined as alteration in the physical, chemical and biological characteristics of water which may cause harmful effects on human and aquatic life. Obviously, water pollution has become a serious environmental problem all over the world and its impact has traditionally been related to public health hazards. India as many other countries of the world also faces the alarming problems of water scarcity and water pollution on a large scale due to rapidly growing cities, burgeoning industries and increase in its population (for example, 238million in 1901 and 1210million at the end of 2011) (Table 1). An estimated 70 per cent of the available water of the Indian rivers is polluted because of improper disposal of untreated sewage and industrial wastes directly into rivers and streams. ${ }^{2}$ Although water is essential for all forms of life, for many it becomes a source of disease burden. In this context we review the main causes of water pollution in India and the diseases resulting from water pollution so as to control water pollution and contamination and protect the availability of India's precious water resources. Moreover, water pollution control is typically one of the responsibilities of the Government as it aims to protect the environment for the good of the general public.

Table I Growth of human population and water availability in India during $1901-201$ I $^{8}$

\begin{tabular}{lllllll}
\hline $\begin{array}{l}\text { Census } \\
\text { Years }\end{array}$ & $\begin{array}{l}\text { Population } \\
\text { (million) }\end{array}$ & Density & $\begin{array}{l}\text { Decadal growth } \\
\text { rate (\%) }\end{array}$ & $\begin{array}{l}\text { Annual growth } \\
\text { rate (\%) }\end{array}$ & $\begin{array}{l}\text { Progressive growth rate } \\
\text { over 1 90 I (\%) }\end{array}$ & $\begin{array}{l}\text { Per capita water } \\
\text { availability }\left(\mathbf{m}^{3}\right)\end{array}$ \\
\hline & & & & & & \\
1901 & 238.4 & 73 & - & - & - & 9652 \\
1911 & 252.1 & 77 & 5.8 & 0.56 & 5.8 & 9127 \\
1921 & 251.3 & 76 & -0.31 & -0.03 & 5.4 & 8247 \\
1931 & 279.0 & 85 & 11.0 & 1.04 & 17.0 & 7220 \\
1941 & 318.7 & 97 & 14.2 & 1.33 & 33.7 & 6372 \\
1951 & 361.1 & 110 & 13.3 & 1.25 & 51.5 & 4197 \\
1961 & 439.2 & 133 & 21.6 & 1.96 & 84.3 & 3368 \\
1971 & 548.2 & 166 & 24.8 & 2.22 & 129.9 & 2719 \\
1981 & 683.3 & 207 & 24.7 & 2.20 & 186.7 & 2236 \\
1991 & 846.4 & 257 & 23.9 & 2.14 & 255.0 & 1902 \\
2001 & 1028.7 & 312 & 21.5 & 1.95 & 331.5 & \\
2011 & 1210.0 & 370 & 17.6 & 1.63 & 407.5 &
\end{tabular}




\section{Location and area of India}

India is located in the southern peninsula of the Asian continent. Lying entirely in the northern hemisphere, the mainland extends from latitudes $8^{0} 4^{\prime}$ to $37^{\circ} 6^{\prime}$ North and from longitudes $68^{\circ} 7^{\prime}$ to $97^{\circ} 25^{\prime}$ East of the Greenwich meridian. Countries having a common border with India are Afghanistan and Pakistan in the north-west, China, Bhutan and Nepal in the north, Myanmar in the east and Bangladesh in the east of west Bengal state. The total area of India is 3,287,263 $\mathrm{km}^{2}$ and is divided into 28 states and 9 union territories. By size; India is the seventh largest country in the world and by population it ranks at number two after China. The population has been growing at a rate of 1.63 per cent every year over the past 10 years from 2001 to 2011 (Table 1). The growth of human population and the depletion of fresh water availability in India are the important issues related to the pollution of the water and as such we first discuss the present status of population in India and its water resources.

\section{Water resources of India}

The availability of water in India is dependent on the annual rainfall from the southwest (June-September) and northeast (OctoberDecember) monsoons and there is much variation in rainfall at the station level. The annual rainfall varies from $10 \mathrm{~cm}$ in west Rajasthan desert to $2500 \mathrm{~cm}$ in Cherrapunji hills in northeast. Thankfully, India has had very rich and reliable measurements of rainfall data of about 3000 stations for the last 100 to 110years with the India Meteorological Department (IMD). On the basis of the available rainfall data, the average annual rainfall of India as a whole is about $117 \mathrm{~cm}, 3,4$ equivalent to about $4000 \mathrm{~km}^{3}$. About 76 per cent of the rainfall occurs during the southwest monsoon, June to September. An estimated about $1400 \mathrm{~km}^{3}$ of water is lost to the atmosphere through the process of evaporation and transpiration and from the remaining $2600 \mathrm{~km}^{3}$ about $731 \mathrm{~km}^{3}$ of water goes into the soil and $1869 \mathrm{~km}^{3}$ result in surface runoff. ${ }^{5}$ Of the $731 \mathrm{~km}^{3}$ of water that enters the soil, $299 \mathrm{~km}^{3}$ is held up as soil moisture and $432 \mathrm{~km}^{3}$ goes as deep seepage and is available as groundwater, ${ }^{6,7}$ Thus the total quantum of water resources of India (the sum of surface and groundwater) is about $2301 \mathrm{~km}^{3}$. Most of the surface water runoff in India is found in rivers and there are 14 major river basins in India (Table 3). Part of their runoff is collected in dams and the remaining is lost to the sea.

Table 2 Vital health and socio- economic parameters ${ }^{9}$

\begin{tabular}{|c|c|c|c|}
\hline Important indicators & $|95|$ & 1991 & 2011 \\
\hline Population in million & 361 & 847 & 1210 \\
\hline Annual population growth rate in \% & 1.25 & 2.14 & 1.63 \\
\hline Density of population in per sq. km & 117 & 267 & 370 \\
\hline Percentage of urban population & 17 & 26 & 28 \\
\hline Sex ratio at birth (girls for every 1000 boys) & 946 & 926 & 933 \\
\hline Number of towns & - & 4615 & 5161 \\
\hline Number of villages & - & 580781 & 638588 \\
\hline Crude birth rate (in every 1000 population) & 40 & 30 & 23 \\
\hline Crude death rate (in every 1000 population) & 28 & 10 & 8 \\
\hline Natural growth rate ( in every 100 population) & 13 & 20 & 16 \\
\hline Infant mortality rate(IMR) (in every 1000 born) & 134 & 80 & 47 \\
\hline Child $(0-4$ years $)$ mortality rate & 57 & 27 & 17 \\
\hline Maternal mortality rate (in every I lakh born) & - & 519 & 254 \\
\hline Expectancy of life in years & 32 & 59 & 62 \\
\hline Gross National Product (Rupees in millions) & 95,060 & $50,34,090$ & $5,15,06,860$ \\
\hline Per capita net national product in Rupees & 255 & 5,365 & 37,851 \\
\hline Health expenditure as percentage of GDP & 0.22 & 0.96 & 0.87 \\
\hline
\end{tabular}

Table 3 Mean annual surface runoff $\left(\mathrm{km}^{3}\right)$ and wastewater generation in million litres daily $(\mathrm{mld})$ of the major river basins of India ${ }^{5}$

\begin{tabular}{|c|c|c|c|c|c|c|c|}
\hline & $\begin{array}{l}\text { Name of the } \\
\text { river basin }\end{array}$ & $\begin{array}{l}\text { Basin area } \\
\left(\mathrm{km}^{2}\right)\end{array}$ & $\begin{array}{l}\text { Average annual } \\
\text { runoff }\left(\mathrm{km}^{3}\right)\end{array}$ & $\begin{array}{l}\text { No. of class I } \\
\text { cities }\end{array}$ & $\begin{array}{l}\text { Wastewater } \\
\text { generation }(\mathrm{mld})\end{array}$ & $\begin{array}{l}\text { No. of class } \\
\text { II cities }\end{array}$ & $\begin{array}{l}\text { Wastewater } \\
\text { generation }(\mathrm{mld})\end{array}$ \\
\hline I & Indus & 321,290 & 80 & 15 & 624 & 20 & 142 \\
\hline 2 & Ganga & 861,404 & 550 & 103 & 5812 & 119 & 628 \\
\hline 3 & Brahmaputra & 187,110 & 591 & 7 & 179 & 9 & 54 \\
\hline 4 & Sabarmati & 21,674 & 4 & 7 & 652 & 6 & 32 \\
\hline 5 & Mahi & 34,842 & $4 I$ & 3 & 161 & 4 & 19 \\
\hline 6 & Narmada & 98,796 & 40 & 4 & 44 & 5 & 25 \\
\hline 7 & Tapi & 65,145 & 20 & 8 & 275 & 5 & 18 \\
\hline 8 & Subarnarekha & 19,300 & 12 & 2 & 280 & 2 & 7 \\
\hline 9 & Brahmani & 39,033 & 29 & $\mathrm{I}$ & 17 & I & 3 \\
\hline 10 & Mahanadi & $|4|, 600$ & 67 & 9 & 413 & 9 & 35 \\
\hline II & Godavari & 312,812 & 116 & 25 & 635 & 37 & 168 \\
\hline 12 & Krishna & 258,948 & 68 & 27 & 1314 & 22 & 90 \\
\hline 13 & Pennar & 55,213 & 7 & 6 & 61 & 5 & 15 \\
\hline 14 & Cauvery & 87,900 & 21 & 16 & 727 & 18 & 51 \\
\hline
\end{tabular}




\section{Growth of human population and fresh water availability in India}

Thankfully, India has had a long history of very rich and reliable demographic data which can be used to assess whether the current human population growth is unprecedented. The data on population (Table 1) tells us that India's population has increased by more than 5 times in the last 110years, from 238.4million in 1901 to 1210 million in 2011. Most of the increase (87\%) happened in the postindependence era (1951-2011). The highest population growth was $24.8 \%$ during 1961-71, after which the growth rate started declining going down to $17.6 \%$ during 2001-11. Although India has witnessed a steady decline in its population growth rate over the last four decades (1971-2011), we have added 662million to our population in this period. India's population is now rising at about $1.63 \%$ every year this means that the population of India will be 1540 million by 2025 and will become the world's most populous country. The growth of population has decreased the availability of fresh water in India. The water availability per capita in India has gone down from $6372 \mathrm{~m}^{3}$ per annum in 1951 to about $1902 \mathrm{~m}^{3}$ in 2011 - the lowest in nearly 6 decades. The phenomenal growth in population has got its environmental cost in terms of water depletion and water pollution. It is worth noting that India accounts for one sixth $(17 \%)$ of global population while land area constitutes only $2.4 \%$.

\section{India's health and socio-economic parameters}

The vital health and socio-economic parameters of India for the years 1951, 1991 and 2011 are presented in Table 2. Data shows that there have been large improvements in the health status parameters in India since independence. The all India sex ratio was 926 girls for every 1000 boys in 1991 went up by 7 points in 2011 after 20long years. The all India life expectancy has gone up from 32years in 1951 to 62 years in 2011. The infant mortality rate (IMR) has fallen from 134 in 1951 to 47 in 2011. Mortality rate is defined as the number of deaths per 1000 population in a given region and time period. The global average IMR is 29 and that for low and middle income countries, the category that India belongs to is 47 . The IMR for the Europeon region is 8 . The crude birth rate has been reduced from 40 in 1951 to 23 in 2011 and the crude death rate from 28 to 8 in the same period. The crude birth rate is the number of live births per year per 1000 midyear population of a given area. It is called crude because it does not take into account age or sex differences among the population. The crude death rate is the number of deaths per year per 1000 midyear population. The number of child below 4 years dying out of every 1000 born alive is considered an important marker of country's health system and as regards to India this has fallen from 57 in 1951 to 17 in 2011. One of the major reasons for these improvements has been the development of improved health services. However, India has one of the lowest health expenditure in the world. The gross national product (GNP) per capita in 2011 was Rupees 37,851 (US\$ 740) with a rate of increase of 21 percent.

\section{Mechanisms of water pollution}

Rainfall is the main source of water in streams, lakes, tanks, ponds, springs, large reservoirs, and shallow and deep wells. Rainwater that becomes available for use from these water bodies contains various types of impurities and higher concentrations of some chemical substances which can have several adverse effects on human health. Water pollution occurs when any substance in undesirable concentration not normally present in water e. g microorganisms, chemicals, waste or sewage enters into water and make the water unfit for its intended use. ${ }^{1}$ Rainwater carries dissolved $\left(\mathrm{O}_{2}\right),\left(\mathrm{CO}_{2}\right)$, and other gases from the atmosphere as well as suspended particles. After falling on the ground and when begins to flow over the soil and rock, the water dissolves the clay, mud, organic and inorganic substances to varying degrees. Furthermore, when it flows in streams, it comes in contact with decomposed vegetables, and dead human and animal bodies. Thus, organic matter gets mixed in the rainwater and this further increase its dissolving capacity and thus some major type of chemical salts such as Carbonates $\left(\mathrm{CO}_{3}\right)$, Sulfates $\left(\mathrm{SO}_{4}\right)$, Chlorides $(\mathrm{Cl})$ and Nitrates $\left(\mathrm{NO}_{3}\right)$ of Calcium $(\mathrm{Ca})$, Magnesium $(\mathrm{Mg})$, and Sodium (Na) get dissolved in water in concentrations greater than 1milligram per litre $(\mathrm{mg} / \mathrm{l})$. In addition there are minor and trace salts of some metals such as Aluminium (Al), Copper $(\mathrm{Cu})$, Iron (Fe), Manganese $(\mathrm{Mn})$, and Zinc $(\mathrm{Zn})$ that regularly occur in water. Excessive use of pesticides and fertilizers may also contaminate the water bodies. The introductions of these substances into the water render the rainwater hard, alkaline and saline and make the water unsafe particularly for domestic (including drinking) use. In addition to these, certain harmful bacteria known as pathogenic micro-organisms are also sometimes enter into the water which causes water-borne diseases and epidemics. Water borne diseases are spread by contamination of drinking water systems with the urine and faeces of infected animal or people. The germs in the faeces can cause the diseases by even slight contact and transfer. The waterborne diseases are the major cause of death globally.

\section{Main causes of water pollution in India}

There are four distinct causes of water pollution in India's water bodies. ${ }^{2}$ These include human activities, industrial discharge, India's religious and social beliefs and agriculture which are briefly described as follows:

\section{Human activities}

Generation of wastes is a part of human activities and its disposal over the land and in water bodies has been a normal practice in India from times immemorial. Rapid growth of population and urbanization in India during the recent decades has given rise to a number of environmental problems such as water scarcity, wastewater generation and its collection, treatment and disposal. Many towns and cities have increased in size tremendously but facilities for the disposal of waste, wastewater; stockpiling, etc have not always been implemented in a satisfactory manner. People have therefore been dumping all sorts of waste matter that includes industrial waste, municipal sewage, residues of chemical fertilizers into our rivers and greatly polluting the river waters as also damaging the urban environment. These wastes are both solids as well as in dissolved state. Also most of the sewage of towns and cities is directly dumped into water sources without any treatment rendering the water downstream unfit for drinking and even for bathing. In urban areas water is supplied for domestic and industrial use from rivers, streams, lakes, ponds, wells etc. Nearly $80 \%$ of the water supplied for domestic use passes out as wastewater. In most cases, this wastewater is let out untreated and causes large scale pollution of the surface water. A part of it percolates into the ground and contaminates the ground water. Table 3 gives the volume of wastewater generated by class I and class II cities situated in different river basins in India. The total waste water generated from Class I and class II cities is as much as 12,481 million litres per day (mld). The Ganga river basin alone contributes about one-third of the total waste water of India. About 70 per cent of the population of class I cities is provided with sewerage facility ${ }^{2}$. These are the symptoms of a lack of regulation and standards if the sole reason for water quality deterioration is human activities. 
Facilities of piped water have been provided in many towns and even in some villages during the last couples of decades. This has resulted in the use of flush-toilets and much larger use of water in homes for bathing, washing of clothes, utensils etc., and generating large quantities of wastewater. The use of soaps and detergents and amounts of various food materials going to sink have also grown considerably with improved standards of living. But sewerage has lagged far behind water supply. Situations in big cities are worsened by the migration of people from the surrounding rural areas. According to an estimate by Central Pollution Control Board (CPCB) which is India's national body for monitoring environmental pollution only about $40-50 \%$ of the population of the major cities like Delhi, Mumbai, Kolkata, Chennai, and Bangalore are served by sewer systems. All the 14 river basins (Table 3) of India have been affected by untreated city sewage. Large scale pollution of rivers is turning them into septic drains posing serious threat to the health of millions of people.

\section{Industrial discharge}

Many industries in India are located on river banks and use the rivers as open sewers for their effluents. The rivers are greatly polluted by such industrial wastes or effluents. All these industrial wastes are toxic to life that consumes this water. The major industries responsible for water pollution in India include pharmaceuticals, distillery fermentation, fertilizer plants, sugar industries, iron and steel industries, textiles, pulp and paper mills, engineering, paint and food. Of all these, the engineering industries presents the greatest threat to water pollution in India. The total waste water generated from all major industrial sources is $83,048 \mathrm{mld}^{2}$.

\section{India's religious and social beliefs}

Most religious beliefs and social activities add to the pollution of our river waters from times immemorial. Carcasses of cattle and other animals are disposed in the rivers. Dead bodies are cremated on the river banks. Partially burnt bodies are flung into the river. All this is done as a matter of religious faith and in keeping with ancient rituals. These practices pollute the river water and adversely affect the water quality. The problem peculiar to Varanasi city arises from the Hindu belief that the dead cremated here attain salvation. This results in hundreds of bodies being cremated at the river bank every day. This amounts to nearly 15,000 tons of ash per month which is dumped into the river. ${ }^{2}$ Mass bathing in a river during religious festivals is another environmentally harmful practice. Studies have revealed that the biochemical oxygen demand (BOD) goes up drastically when thousands of people simultaneously take a holy dip. Religious beliefs in India also demands that offerings from religious prayers be immersed in a river. It is now common to see people immersing offerings in plastic bags which are very dangerous and further add to the pollution load of the river.

\section{Agriculture practices}

Agriculture is one of the most widespread human activities in India that can affect surface water bodies. The agriculture practices include the cultivation of crops, cattle and poultry farming, fish farming, logging, etc. The use of chemical fertilizers and pesticides, the storage and disposal of manure, stockpiling of materials is diffused throughout the river basin and that surface water resources get affected. Although irrigation has increased considerably in the country, not much has been done to tackle the problem of the high salinity water flow. For example, in Haryana, the 40km long drain pours $250,000 \mathrm{~kg} /$ day of chloride into the Yamuna river to raise the chloride concentration in the river from $32 \mathrm{mg} / 1$ at upstream of the drain confluence to $150 \mathrm{mg} / 1$ at downstream of it. According to the Agricultural Research Institute (IARI), New Delhi, farmers often indulge in excess usage of fertilizers and pesticides. Obviously, when these are used more than the recommended doses, they pollute water, land and air.

\section{Occurrence of diseases from water pollution in India}

$\mathrm{UNESCO}^{1}$ definition of water pollution is introduction into water of any substance in undesirable concentration not normally present in water, for example, microorganisms, chemicals, waste or sewage, which renders the water unfit for its intended use. About $80 \%$ of stomach diseases in India are caused by the lack of safe water with inadequate sanitation. Water pollution adversely affects the health and life of man, animals and plants alike. Polluted water is also harmful for agriculture as it adversely affects the crops and the soil fertility. Consumption of polluted water is a major cause of ill health in India through waterborne diseases. Waterborne diseases occur worldwide and are caused by pathogenic micro-organisms that often come in water from human or animal waste. Some of the deadly water borne diseases is Cholera, Typhoid, Paratyphoid fever, Dysentery, Diarrhea, Tuberculosis, Jaundice, and Amoebiasis etc. Waterborne diseases are single most important factor responsible for nearly $80 \%$ of human mortality in India. Children are worst affected, especially in rural areas and urban slums. Unsafe drinking water contributes to high infant mortality when it is contaminated with excreta or fecal matter.

The lacks of safe water with inadequate sanitation combined with poor environmental status determine transmission of the cholera disease. Cholera and water environmental pollution issues therefore are closely linked Cholera is presently one of the main causes of morbidity and mortality in India. Cholera is a notifiable disease in most countries. Table $4 \&$ Figure 1 show the number of cholera cases and the resulting deaths that were notified during 1950 to 1984 . Table is based on cholera data set available from the health statistics of India published by the Ministry of Health and Family welfare, Government of India, New Delhi. The Figure shows that the high number of cholera cases with the exception of 1954, 1955, 1960 and 1962 occurred particularly during 1950 to 1965 and then there has been steady decline in the number of cholera cases. The cholera cases in India peaked in number in 1953. Even today cholera epidemics occur regularly in India and it is unlikely that cholera will be eradicated. Nevertheless, recently mass vaccination against cholera has been added to control cholera.

High concentrations of different inorganic substances and trace metals in the water due to industrial pollution, also pose a serious health risk to the people. The major inorganic substances in water include sodium, potassium, calcium, magnesium, bicarbonate, sulfate and chloride and the trace metals include aluminium, arsenic, boron, cadmium, chromium, copper, lead, nickel, zinc, etc. The distribution of these chemicals largely depends on the type of geological formations in contact with the flowing water. High concentrations of calcium and magnesium compounds cause hardness of water. For people suffering from diseases of the heart or kidneys, it is recommended to avoid drinking water with high concentrations of sodium. If chloride concentration is more than $250 \mathrm{mg} / \mathrm{l}$ or if $\left(\mathrm{H}_{2} \mathrm{~S}\right)$ is present in drinking water, the water will acquire undesirable tastes and odors. Also if sulfate concentration is more than $250 \mathrm{mg} / 1$, a laxative effect is produced on human body. The lead and barium salts are toxic and only very low concentration is permitted. Similarly, Arsenic, and Selenium 
are poisonous and very low concentration of these salts can be tolerated by the human system. The consumption of water with high level of arsenic may lead to the loss of limbs, cancer, or death as prevalent in some parts of the West Bengal state of India. Long term exposure to arsenic has produced widespread arsenicosis, mainly manifested in skin ailments, as well as diabetes mellitus, vascular disease and neuropathy and also wide spread heart and lung disease and multiple cancers. The permissible arsenic level in drinking water is $0.01 \mathrm{mg} / \mathrm{L}$. Fluorine (fluoride) is beneficial to human health in low concentration but is toxic in excess. Numerous studies have demonstrated that low concentrations in drinking water $(0-0.5 \mathrm{mg} / \mathrm{l})$ are associated with increased dental caries (tooth decay) rates, whereas contents of $0.5-1.5 \mathrm{mg} / 1$ are protective against the disease. As a result fluoride is widely used in dental products. However, the drinking of water with high concentrations of fluoride may cause mottled teeth and disturb the growth of bones in children. The recommended limits for different chemicals are listed in Table 7. The Table 5 gives the list of diseases caused by water pollution.

\section{Water quality in relation to health}

The standard of water quality varies considerably according to the intended water use. However, all waters are not suitable for drinking and cooking purposes and there are the most stringent criteria applied to water quality in the provision of drinking water supplies in India. From the quality point of view the water supply engineer is most concerned with the three main parameters of water qualities as shown in Table 6 . The drinking water must be colorless, odorless and tasteless. It should be free from chemical compounds. But we know chemically pure water is not safe to drink, minerals are essential for good health. Harmful micro-organisms and radio-activity must be absent.

World Health Organization ${ }^{12}$ has laid down its International Standards for water quality for drinking purposes. The maximum permissible limits of various inorganic constituents which are generally accepted in India for drinking use as per Indian standards ${ }^{13}$ are listed in Table 7 . When these water standards are not adequate, the water may not be $100 \%$ fit for drinking and may be termed as contaminated. The major inorganic substances form the majority of chemical compounds found in water. The summed concentration of minerals dissolved in water is referred to as total dissolved solids (TDS). There is no evidence of adverse health effects at TDS levels over $1000 \mathrm{mg} / 1$, although at about $1,200 \mathrm{mg} / 1$ taste problems are likely to arise, and at levels over $1,500 \mathrm{mg} / 1$, gastrointestinal irritation may occur.

Table 4 Notified cases \& deaths of Cholera in India: 1950- $1984^{10}$

\begin{tabular}{lllllllll}
\hline Year & Cases & Deaths & Year & Cases & Deaths & Year & Cases & Deaths \\
\hline 1950 & $1,76,307$ & 86997 & 1962 & 27,165 & 9,403 & 1974 & 30,997 & 2,189 \\
1951 & 86,835 & 42,070 & 1963 & 56,988 & 20,309 & 1975 & 21,955 & 2,320 \\
1952 & $1,01,248$ & 48,404 & 1964 & 56,436 & 19,836 & 1976 & 17,492 & 861 \\
1953 & $2,10,239$ & 93,323 & 1965 & 43,285 & 12,947 & 1977 & 9,091 & 538 \\
1954 & 22,065 & 10,669 & 1966 & 13,027 & 2,788 & 1978 & 10,708 & 263 \\
1955 & 23,797 & 10,555 & 1967 & 13,658 & 3,122 & 1979 & 5,638 & 312 \\
1956 & 39,759 & 17,120 & 1968 & 22,587 & 4,472 & 1980 & 8,717 & 309 \\
1957 & 56,007 & 22,996 & 1969 & 19,280 & 3,757 & 1981 & 6,073 & 200 \\
1958 & 66,076 & 28,180 & 1970 & 17,268 & 3,801 & 1982 & 4,693 & 217 \\
1959 & $1,14,937$ & 15,418 & 1971 & 17,140 & 3,595 & 1983 & 9,202 & 432 \\
1960 & 14,167 & 5,250 & 1972 & 21,344 & 2,908 & 1984 & 2,642 & 68 \\
1961 & 47,637 & 16,334 & 1973 & 40,855 & 5,308 & - & - & - \\
\hline
\end{tabular}

Table 5 Water pollution and the resulting diseases ${ }^{\prime \prime}$

\begin{tabular}{|c|c|c|c|}
\hline S.no. & Name of pollutant & Sources of pollution & Diseases \\
\hline I & Detergent & Washing of clothes & $\begin{array}{l}\text { Depletes the oxygen of water endangering } \\
\text { aquatic life. }\end{array}$ \\
\hline 2 & Sewage waste & Untreated human excreta into rivers & $\begin{array}{l}\text { Diseases such as cholera, typhoid, } \\
\text { jaundice, diarrhea etc. }\end{array}$ \\
\hline 3 & Industrial effluents & Waste products from factories & These are toxic substances. \\
\hline 4 & Fertilizers & Washed out of soil by rain to rivers & Increase toxicity of the water. \\
\hline 5 & Pesticides & Enter into water from the soil & Poisonous substances. \\
\hline 6 & Metallic pollutants: $\mathrm{Hg}, \mathrm{Cd}, \mathrm{As}, \mathrm{Cu}, \mathrm{Pb}, \mathrm{Zn}, \mathrm{Cr}, \mathrm{Al}, \mathrm{Co}$ & Industries & $\begin{array}{l}\text { Cancer, neurological ailments, lung diseases } \\
\text { etc. }\end{array}$ \\
\hline 7 & Organic pollutants & Dead plants \& animals in water & $\begin{array}{l}\text { Deoxygenate the water, endangering fish } \\
\text { life. }\end{array}$ \\
\hline 8 & Fluorides & Industries & Dental \& skeletal fluorosis. \\
\hline 9 & Oil & Oil tankers travelling through sea & Oil spread over seawater surface. \\
\hline
\end{tabular}


Table 6 Water quality parameters

\section{Characteristics Parameters}

Physical features Color, taste, odor, suspended \& dissolved solids, radioactivity

Chemical substances Bicarbonate $\left(\mathrm{HCO}_{3}\right)$, Chloride $(\mathrm{Cl})$, Sulfate $\left(\mathrm{SO}_{4}\right), \mathrm{Ca}, \mathrm{Fe}, \mathrm{P}, \mathrm{N}_{2}, \mathrm{Mg}, \mathrm{Fe}$

Biological features Coliforms, fecal coliforms, pathogens and viruses

Table 7 Maximum permissible concentrations of inorganic constituents in drinking water in $\mathrm{mg} / \mathrm{I}^{12,13}$

\begin{tabular}{|c|c|c|c|}
\hline Constituent & Concentration (mg/l) & Constituent & Concentration (mg/l) \\
\hline $\mathrm{pH}$ & $6.5-8.5$ & Iron (Fe) & 0.3 \\
\hline Total dissolved solids & 500 & Lead $(\mathrm{Pb})$ & 0.01 \\
\hline Aluminum (Al) & 0.03 & Mercury $(\mathrm{Hg})$ & 0.01 \\
\hline Ammonia $\left(\mathrm{NH}_{3}\right)$ & 0.5 & Magnesium (Mg) & 30 \\
\hline Arsenic (As) & 0.01 & Manganese (Mn) & 0.1 \\
\hline Boron (B) & 0.5 & Mineral oil & 0.5 \\
\hline Barium (Ba) & 0.7 & Nitrate & 45 \\
\hline Calcium (Ca) & 75 & Nickel (Ni) & 0.02 \\
\hline Chloride $(\mathrm{Cl})$ & 250 & Phenolic compound & 0.001 \\
\hline Chromium (Cr) & 0.05 & Selenium (Se) & 0.01 \\
\hline Copper (Cu) & 0.05 & Sulfate $\left(\mathrm{SO}_{4}\right)$ & 250 \\
\hline Cadmium (Cd) & 0.003152 & $\mathrm{CaCO}_{3}$ & 0.1 \\
\hline Cyanide $(\mathrm{CN})$ & 0.05 & Zinc (Zn) & 5 \\
\hline Fluoride (F) & $\mathrm{I} .0$ & B.O.D & Nil \\
\hline
\end{tabular}

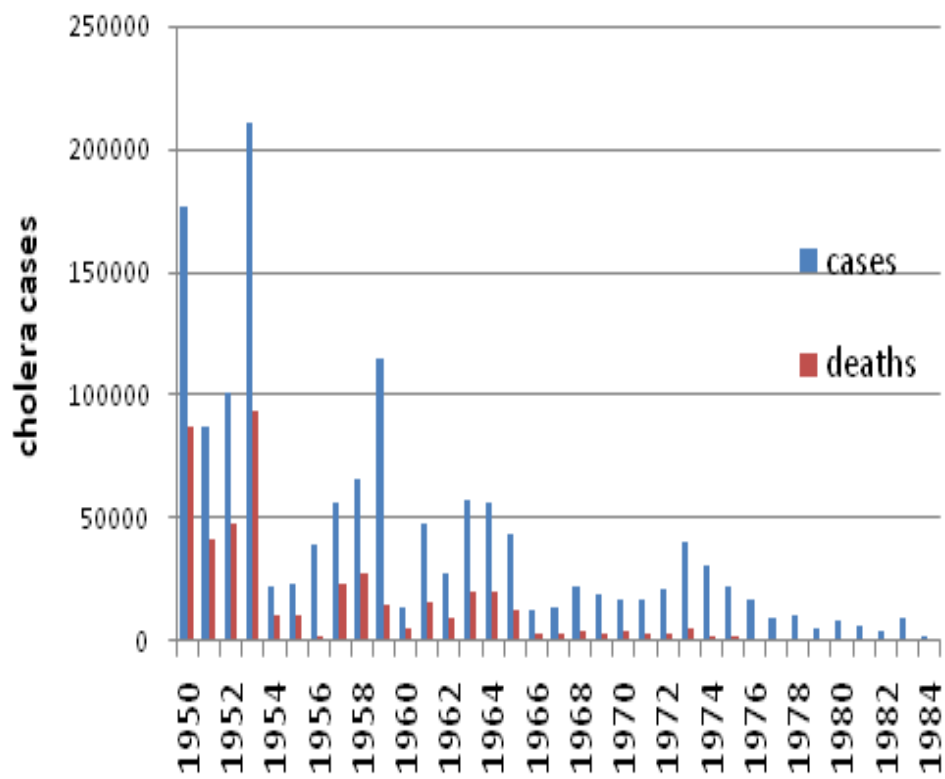

years

Figure I Number of cholera cases and deaths in India (1950 -1984).

\section{Water quality in the Indian rivers}

Most of the surface water in India is found in rivers and there are 14 major river basins in India (Table 3). The quality of waters available in these rivers is as follows:

\section{Total salt content}

The rivers of central India (Tapi, Narmada, Godavari, and Krishna) have higher concentrations of soluble salts as compared to the north Indian rivers (Indus, Ganga and Brahmaputra) which flow through the alluvial regions. Bicarbonates and chlorides of sodium, calcium, magnesium, and potassium are generally present in waters, while some carbonates are also present during the periods of low flow. The carbonate content is relatively more in rivers of central India. The chloride content is relatively low in north Indian rivers. The sodium content is quite low throughout the country but its amount varies during the year in the case of south Indian rivers. The total 
concentration of soluble salts is generally low but increases slightly during the low flow.

\section{Water hardness}

The waters of Ganga and Mahi Rivers are hard: on the other hand, the waters of southern India Rivers are generally soft and are quite suitable for boilers. Both heart disease and high blood pressure can be caused by drinking hard water.

\section{Acidity and alkalinity}

Most of the Indian River waters are alkaline. However, the waters of Ravi, Jhelam, Ramganga and Chambal etc. are acidic for a few months during the year.

\section{Salinity and alkalinity}

Most of the waters of northern and southern India Rivers are considered excellent for agriculture.

\section{Conclusions}

The rapid growth of population in India has led a number of water related problems which are relevant to public health. Although the economy of India has grown after independence in 1947 and in spite of an improvement in life expectancy and provision of potable water there still remains a great deal of progress to be made. The main impediment to improvement seems to be cultural rather than technical or economic. The Indian Government should attempt to educate the younger generation in schools, colleges and universities so that while respecting the cultural practices of the past they could still be carried out in a more controlled and less water polluting way. The care of people is made paramount to all civilizations regardless of their cultural and religious background.

\section{Acknowledgments}

None.

\section{Conflicts of interest}

Authors declare no conflict of interest exists.

\section{Funding}

None.

\section{References}

1. UNESCO. International Glossary of Hydrology. $2^{\text {nd }}$ edn, UNESCO, Paris, France; 1992. p. 413.

2. Khullar DR. A comprehensive geography. $2^{\text {nd }}$ edn, Kalyani Publishers, New Delhi; 2005.

3. Dhar ON, Rakhecha PR. A review of hydro meteorological studies of Indian rainfall. Proc. Second World Congress on Water Resources organized by International Water Resources Association, held at New Delhi. 1975;3:449-462.

4. Dhar ON, Rakhecha PR. A review of rainfall relationship based upon Indian data. Water Resources Journal ESCAP, Bangkok. 1979;16-25.

5. Rao KL. India's Water Wealth. Orient Longman, New Delhi; 1975.

6. Central Ground Water Board (CGWB). Bhu Jal News (Special issue on groundwater statistics). Ministry of Water Resources Publ. Government of India. 1991;6:1-162.

7. Chadha DK. Development of groundwater resources of India: A overview. Groundwater modeling and management. Capital Publishing Company, New Delhi; 2006.

8. Ministry of Information \& Broadcasting (MIB). A Reference Manual. MIB Publ Government of India, New Delhi; 2012.

9. KIshore J. National health programs of India. $9^{\text {th }}$ edn, Century Publications, New Delhi; 2011.

10. Ministry of Health and Family Welfare (MHFw). Health Statistics of India. Government of India, New Delhi;1985.

11. Gupta MK. Health charts \& Tables for you. $2^{\text {nd }}$ edn, Pustak Mahal Publishers, New Delhi; 1997.

12. World Health Organization (WHO). Guidelines for drinking water quality, recommendations. Geneva, Switzerland; 1984. p. 130.

13. Bureau of Indian Standards (BIS). Drinking water specification. IS 10500 , New Delhi; 1992. 